\section{p-ISSN 2476-9886 \\ e-ISSN 2477-0302 \\ J.Edu}

Volume 4 Nomor 2, November 2018, HIm 92-99

\section{Jurnal EDUCATIO}

Jurnal Pendidikan Indonesia

DOI: https://doi.org/10.29210/120182257
Akses Online :

http://jurnal.iicet.org

Info Artikel:

Diterima: 03/12/2018 Direvisi: 14/12/2018_ Dipublikasikan: 15/12/2018

\title{
Social environment factors and its relationship with the appreciation of the character of polytechnic students
}

\author{
Shaiffuddin Bin Anuar ${ }^{1}$, Norni Binti Abdul Wahab ${ }^{2}$ \\ ${ }^{12}$ Politeknik Sultan Mizan Zainal Abidin
}

\begin{abstract}
Social environment can influence students' moral. This study aimed to see the influence and relevance of such relationships. Social environment in this study includes parents, teachers, peers, artists, environmental institutions, communities and discipline enforcement. This quantitative study carried out against 400 student semester one Sultan Mizan Zainal Abidin Polytechnic as samples. Consists of students of Department of Electrical Engineering and Department of Mechanical Engineering. Both departments were chosen because they have student majority. The results show that social environment influential significantly against the formation of students ' moral character. The highest influence of social environment is the parent $(M=4.25, S D=0.57)$, followed by teachers $(M=3.97, S D=0.61)$, society $(M=3.81, S D=0.60)$, the institutional environment $(M=3.76, S D=0.59)$, discipline enforcement $(M=3.74, S D=0.73)$, peers $(M=3.63, S D=0.62)$ and artists $(M=2.80, S D=0.93)$. The findings contribute to the improvement of teaching and learning activities and development of students ' moral character in the institution as a whole.
\end{abstract}

Keywords: social environment factors, character, polytechnic students

(c) (i) This is an open access article distributed under the Creative Commons Attribution License, which permits unrestricted use,

\section{PENDAHULUAN}

Faktor-faktor persekitaran sosial boleh mempengaruhi atau menjadi sumber pembelajaran kepada proses pembentukan tingkah laku seseorang melalui pelbagai corak pembelajaran sosial seperti permodelan, maklum balas, dorongan dan halangan (Azhar Ahmad, 2006). Faktor persekitaran sosial yang dimaksudkan termasuklah elemen-elemen kemanusiaan, seperti pengaruh ibu bapa, pengaruh guru-guru, pengaruh rakan sebaya dan pengaruh masyarakat, atau juga elemen-elemen bukan kemanusiaan seperti pengaruh pelbagai jenis media yang diterima oleh seseorang semasa menjalani proses kehidupan mereka.

Selain daripada peranan diri, pembentukan keperibadian seseorang turut dipengaruhi oleh pelbagai pengaruh yang wujud dalam persekitaran kehidupan manusia seperti mana yang dijelaskan dalam al-Quran ayat ke 8 hingga ke 10 surah asy-Syams:

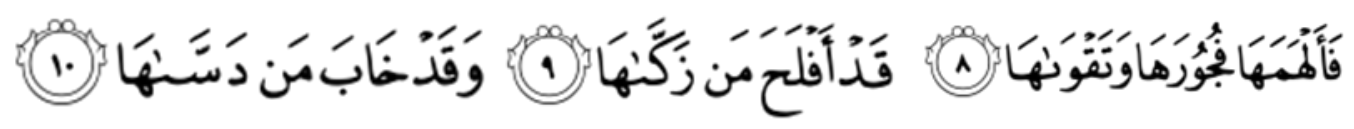

Serta mengilhamkannya (untuk mengenal) jalan yang membawanya kepada kejahatan, dan yang membawanya kepada bertaqwa; Sesungguhnya berjayalah orang yang menjadikan dirinya - yang sedia bersih bertambah-tambah bersih (dengan iman dan amal kebajikan), Dan sesungguhnya hampalah orang yang 
menjadikan dirinya - yang sedia bersih - itu susut dan terbenam kebersihannya (dengan sebab kekotoran maksiat). (Asy-Syams 91: 8 - 10)

Dalam ayat ini dijelaskan tentang proses pembentukan keperibadian manusia dipengaruhi oleh elemenelemen ilham sama ada ia menuju kepada jalan yang baik mahupun yang buruk. Namun manusia dibekalkan dengan akal untuk memilih jalan mana yang harus diikuti. Pengaruh-pengaruh jalan kebaikan dan kefasikan ini pada hakikatnya merupakan pengaruh-pengaruh yang wujud daripada persekitaran dalam kehidupan seseorang. Rasulullah saw juga telah menghuraikan pentingnya elemen pengaruh persekitaran sosial terhadap proses pembentukan keperibadian seseorang. Baginda menjelaskan tentang pentingnya seseorang memperhatikan dengan siapakah dia bergaul dalam kehidupan sehariannya kerana pergaulan tersebut akan memberi kesan terhadap keperibadiannya

Imam al-Ghazali juga turut menekankan faktor pembelajaran sosial iaitu pergaulan dengan orang-orang yang soleh sebagai salah satu daripada tiga kaedah membentuk akhlak yang mulia dalam diri seseorang (Muhamad Abul Quasem 1975). Ini adalah kerana manusia itu secara semulajadi bersifat meniru di mana seseorang itu boleh memperolehi kedua-dua sifat baik dan buruk daripada keadaan seseorang yang lain. Jika seseorang itu bergaul dengan seseorang yang baik dalam tempoh tertentu, dia akan memperolehi dalam dirinya sesuatu kebaikan daripada orang tersebut dan secara tidak disedari banyak mempelajari sesuatu daripadanya (M. Umaruddin 2003). Menurut Badrulzaman (2006) pula, manusia berbeza berdasarkan persekitaran di mana ia berada. Sesiapa yang mendapati dirinya berada dalam persekitaran dan pendidikan yang membantunya ke arah kebaikan, maka dia lebih cenderung untuk menjadi golongan yang baik dan begitu juga sebaliknya.

Ibn Khaldun (2002) juga menjelaskan, persekitaran yang baik perlu bagi menghasilkan akhlak yang baik dan akhlak yang baik itu perlu lahir dari diri sendiri berdasarkan pengamatannya kepada faktor-faktor persekitaran yang boleh mempengaruhi tabiat hidup manusia. Hassan (1987) berpendapat, persekitaran mampu memberi kesan terhadap penghayatan nilai akhlak seseorang. Menurut beliau, penghayatan nilai akhlak merupakan peringkat akhir dari proses pengakuran sosial yang dibentuk melalui pembelajaran sosial yang menggabungkan asas-asas pembelajaran sosial seperti rangsangan, tindak balas, peneguhan, kepatuhan, identifikasi, permodelan dan tiruan. Proses ini selanjutnya memerlukan kewujudan faktor-faktor motivasi luaran seperti galakan dan ancaman dan dalaman seperti kepuasan diri dan keinginan untuk dilihat

\section{METODE}

Rekabentuk kajian ini adalah kuantitatif menggunakan kaedah tinjauan (survey) dengan menggunakan instrumen soal selidik Ab Halim et. al. (2011) bagi pemerolehan data dengan tahap kebolehpercayaan yang tinggi iaitu 0.841 seperti Jadual 1 berikut:

Jadual 1: Kebolehpercayaan Instrumen Penelitian

\begin{tabular}{ccc} 
Aspek & Bil Item & Nilai Alpha \\
\hline Pengaruh Persekitaran & 28 & 0.841 \\
\hline
\end{tabular}

Kajian ini melibatkan populasi iaitu kesemuanya 400 orang pelajar semester satu bagi sesi pengajian Jun 2018 bagi Politeknik Sultan Mizan Zainal Abidin. Kumpulan pelajar ini merupakan pelajar yang telah menamatkan pengajian peringkat SPM 2017. Persampelan yang diguna ialah purposive sampling iaitu persampelan bertujuan sebagaimana yang dicadangkan oleh Creswell (2008) yang mengatakan persampelan bertujuan boleh dilaksana sekiranya sampel yang dipilih mewakili sample yang sebenar lantaran hambatan yang tertentu seperti untuk menjimatkan masa dan kos. Pengkaji juga merujuk kepada jadual sampling Krecjie \& Morgan ( 1970) yang mengatakan jumlah 400 memadai untuk mewakili populasi yang mencecah 100,000.00 populasi. Sehubungan itu pengkaji memilih hanya pelajar dari JKM dan JKE sahaja memandangkan keduanya mempunyai jumlah pelajar yang paling ramai. Data telah ditadbir sendiri oleh pengkaji dan dianalisis secara deskriptif menggunakan peratus, min dan sisihan piawai. Min yang diperoleh ditafsirkan menggunakan cara interpretasi dapatan statistik deskriptif yang dicadangkan oleh Norasmah (2001) dan Azhar (2006) seperti jadual 2 berikut: 
Jadual 2: Interpretasi Skor Min

\begin{tabular}{cc} 
Skor Min & Interpretasi \\
\hline $\mathbf{1 . 0 0}-\mathbf{2 . 0 0}$ & Rendah \\
$\mathbf{2 . 0 1}-\mathbf{3 . 0 0}$ & Sederhana Rendah \\
$\mathbf{3 . 0 1}-\mathbf{4 . 0 0}$ & Sederhana Tinggi \\
$\mathbf{4 . 0 1}-\mathbf{5 . 0 0}$ & Tinggi \\
\hline
\end{tabular}

Sumber: Azhar (2006) dan Norasmah (2001)

\section{HASIL DAN PEMBAHASAN}

\section{Latar Belakang Responden Kajian}

Jadual 3: Latar Belakang Responden Kajian

\begin{tabular}{llll} 
Perkara & Latarbelakang & $\mathrm{N}$ & $\%$ \\
\hline Jantina & Lelaki & 282 & 70.3 \\
\multirow{2}{*}{ Program JKE } & Perempuan & 118 & 29.7 \\
& Diploma Kejuruteraan Elektronik (Komputer) & 48 & 12.0 \\
& Diploma Kejuruteraan Elektronik (Komunikasi) & 20 & 5.2 \\
& Diploma Kejuruteraan Elektrik Dan Elektronik & 54 & 13.5 \\
Program JKM & Diploma Teknologi Digital & 34 & 8.3 \\
& Diploma Kejuruteraan Mekanikal & 108 & 27.1 \\
& Diploma Kejuruteraan Mekanikal (Automotif) & 58 & 14.6 \\
& Diploma Kejuruteraan Mekanikal (Pembuatan) & 44 & 10.9 \\
\hline
\end{tabular}

Sumber: Data Lapangan

Jadual 3 di atas menunjukkan taburan 400 orang responden yang terlibat dengan kajian ini yang mana seramai 282 orang $(70.3 \%)$ adalah pelajar lelaki dan 118 orang $(29.7 \%)$ adalah pelajar perempuan. Kajian ini melibatkan 156 orang (39\%) pelajar dari Jabatan Kejuruteraan Elektrik dan 244 orang (61 \%) pelajar dari Jabatan Kejuruteraan Mekanikal. Jadual 3 juga memaparkan taburan pelajar berdasarkan program pengajian yang diikuti.

\section{Pengaruh Persekitaran Sosial}

Hasil kajian aspek pengaruh persekitaran sosial terhadap pembentukan akhlak pelajar pula dipaparkan secara terperinci berdasarkan jadual 4- 10 di bawah:

1. Pengaruh Ibu bapa

\section{Jadual 4: Taburan skor Pengaruh ibu bapa}

\begin{tabular}{llll} 
Item & Min & SP & Tahap \\
\hline Tingkah laku ibu bapa menjadi ikutan saya & 4.04 & 0.91 & $\mathrm{~T}$ \\
Maklumbalas ibu bapa mempengaruhi akhlak saya & 4.17 & 0.74 & $\mathrm{~T}$ \\
Ibu bapa merupakan faktor pendorong amalan berakhlak saya & 4.48 & 0.62 & $\mathrm{~T}$ \\
Nasihat ibu bapa menjauhkan saya dari perlakuan tidak berakhlak & 4.30 & 0.92 & $\mathrm{~T}$ \\
Keseluruhan & 4.25 & 0.57 & $\mathrm{~T}$ \\
\hline
\end{tabular}

Sumber: Data Lapangan

SP: Sisihan Piawai

R: Rendah SR: Sederhana Rendah

ST: Sederhana Tinggi T: Tinggi

Merujuk kepada jadual di atas, tahap pengaruh ibu bapa dalam pembentukan akhlak anak-anak berada pada tahap tinggi (Skor Min 4.25, SP=0.57) secara keseluruhannya. Skor Min adalah antara $4.04(\mathrm{SP}=0.91)$ bagi item 'Tingkah laku ibu bapa menjadi ikutan saya' iaitu pada tahap tinggi sehingga Skor Min 4.48 (SP=0.62) bagi item 'Ibu bapa pendorong utama amalan berakhlak saya '. pada tahap tinggi. Kesemua item yang dikaji berada pada tahap tinggi. Ini menunjukkan ibubapa mempunyai pengaruh yang tinggi dalam membentuk akhlak pelajar. 
Dapatan ini jugamemperlihatkan intitusi keluarga masih signifikandan utuh dalam membentuk dan memberipengaruh dalam pembentukan akhlak pelajar.

2. Pengaruh Pensyarah

\section{Jadual 5: Taburan skor Pengaruh Pensyarah}

\begin{tabular}{llll} 
Item & Min & SP & Tahap \\
\hline Tingkah laku pensyarah menjadi ikutan saya & 3.63 & 0.94 & ST \\
Maklumbalas pensyarahmempengaruhi akhlak saya & 3.85 & 0.74 & ST \\
Pensyarah merupakan faktor pendorong amalan berakhlak saya & 3.96 & 0.71 & ST \\
Nasihat pensyarah menjauhkan saya dari perlakuan tidak berakhlak & 3.97 & 0.76 & ST \\
Keseluruhan & 3.97 & 0.61 & ST \\
\hline
\end{tabular}

Sumber: Data Lapangan

SP: Sisihan Piawai

R: Rendah SR: Sederhana Rendah

ST: Sederhana Tinggi T: Tinggi

Merujuk kepada jadual 5 di atas, tahap pengaruh pensyarah dalam pembentukan akhlak pelajar berada pada tahap sederhana tinggi (Skor Min 3.97, SP=0.61) secara keseluruhannya. Skor Min adalah antara 3.63 $(\mathrm{SP}=0.94$ ) bagi item `tingkah laku pensyarah menjadi ikutan saya' sehingga Skor Min $3.97(\mathrm{SP}=0.71)$ bagi item 'nasihatpensyarah menjauhkan saya dari perlakuan tidak berakhlak' pada tahap sederhana tinggi. Kesemua item berada pada tahap sederhana tinggi, dapatan ini menunjukkan bahawa pengaruh pensyarah adalah sederhana tinggi dalam membentuk akhlak pelajar. Dapatan ini sekaligus memperlihatkan bahawa institusi pendidikan dan pensyarah tetap berupaya memberi pengaruh dalam pembentukan akhlak dalam kalangan pelajar walaupun berada pada tahap sederhana tinggi.

3. Pengaruh Rakan

\section{Jadual 6: Taburan skor Pengaruh Rakan}

\begin{tabular}{llll} 
Item & Min & SP & Tahap \\
\hline Tingkah laku rakan menjadi ikutan saya & 3.48 & 0.89 & ST \\
Maklumbalas rakan mempengaruhi akhlak saya & 3.68 & 0.86 & ST \\
Rakan merupakan faktor pendorong amalan berakhlak saya & 3.76 & 0.87 & ST \\
Nasihat rakan menjauhkan saya dari perlakuan tidak berakhlak & 3.58 & 1.00 & ST \\
Keseluruhan & 3.63 & 0.62 & ST \\
\hline
\end{tabular}

Sumber: Data Lapangan

SP: Sisihan Piawai

R: Rendah SR: Sederhana Rendah

ST: Sederhana Tinggi T: Tinggi

Merujuk kepada jadual 6 di atas, tahap pengaruh rakan dalam pembentukan akhlak pelajar berada pada tahap sederhana tinggi (Skor Min 3.63, SP=0.62) secara keseluruhannya. Skor Min adalah antara 3.48 $(\mathrm{SP}=0.89)$ bagi item 'tingkah laku rakan menjadi ikutan saya' sehingga Skor Min 3.76 ( $\mathrm{SP}=0.87)$ bagi item 'rakan merupakan faktor pendorong amalan berakhlak saya'. Kesemua item berada pada tahap sederhana tinggi, dapatan ini menunjukkan bahwa rakan mempunyai pengaruh yang sederhana tinggi dalam pembentukan akhlak pelajar. Dapatan memperlihatkan pengaruh rakan sebaya menghampiri pengaruh pensyarah dalam pembentukan akhlak pelajar berkemungkinan lebih banyak masa bersama rakan berbanding pensyarah. 


\section{Pengaruh Artis}

\section{Jadual 7: Taburan skor Pengaruh Artis}

\begin{tabular}{llll} 
Item & Min & SP & Tahap \\
\hline Tingkah laku artis menjadi ikutan saya & 2.50 & 1.12 & SR \\
Maklumbalas artis mempengaruhi akhlak saya & 2.77 & 1.09 & SR \\
Artis merupakan faktor pendorong amalan berakhlak saya & 2.89 & 1.13 & SR \\
Nasihat artis menjauhkan saya dari perlakuan tidak berakhlak & 3.07 & 1.12 & ST \\
Keseluruhan & 2.80 & 0.93 & SR \\
\hline
\end{tabular}

Sumber: Data Lapangan

SP: Sisihan Piawai

R: Rendah SR: Sederhana Rendah

ST: Sederhana Tinggi T: Tinggi

Merujuk kepada jadual 7 di atas, tahap pengaruh artis dalam pembentukan akhlak anakanak berada pada tahap sederhana rendah (Skor Min 2.80, SP=0.93) secara keseluruhannya. Skor Min adalah antara 2.50 $(\mathrm{SP}=1.12$ ) bagi item 'tingkah laku artis menjadi ikutan saya' iaitu pada tahap sederhana rendah sehingga Skor Min 3.07 ( $\mathrm{SP}=1.12)$ bagi item 'nasihat artis menjauhkan saya dari perlakuan tidakberakhlak' pada tahap sederhana tinggi. Kesemua item berada pada tahap sederhana rendah kecuali satu item berada pada tahap sederhana tinggi. Dapatan ini menunjukkan bahawa artis hanya mempengaruhi pembentukan akhlak pelajar pada tahap yang sederhana rendah. Walaupun remaja kini dilihat berminat dengan artis, mengenali dan mengikuti perkembangan artis, artis kurang memberi pengaruh kepada pembentukan akhlak pelajar.

5. Pengaruh Institusi

\section{Jadual 8: Taburan skor Institusi}

\begin{tabular}{|c|c|c|c|}
\hline Item & Min & SP & Tahap \\
\hline Persekitaran institusi menjadi panduan akhlak diri saya. & 3.78 & 0.79 & ST \\
\hline $\begin{array}{l}\text { Tindakan yang diambil terhadap salah laku pelajar melalui peraturan } \\
\text { mempengaruhi pembentukan akhlak diri saya. }\end{array}$ & 3.76 & 0.74 & ST \\
\hline $\begin{array}{l}\text { Persekitaran institusi faktor pendorong yang kuat untuk saya mengamalkan } \\
\text { sikap dan tingkah laku berakhlak. }\end{array}$ & 3.83 & 0.76 & ST \\
\hline $\begin{array}{l}\text { Persekitaran institusi menjadi benteng untuk diri saya dari melakukan perkara } \\
\text { yang tidak berakhlak. }\end{array}$ & 3.68 & 0.80 & $\mathrm{ST}$ \\
\hline Keseluruhan & 3.76 & 0.59 & ST \\
\hline
\end{tabular}

Sumber: Data Lapangan SP: Sisihan Piawai

R: Rendah SR: Sederhana Rendah

ST: Sederhana Tinggi T: Tinggi

Merujuk kepada jadual 8 di atas, tahap pengaruh persekitaran institusi dalam pembentukan akhlak pelajar berada pada tahap sederhana tinggi (Skor Min 3.76, SP=0.59) secara keseluruhannya. Skor Min adalah antara 3.68 ( $\mathrm{SP}=0.79)$ bagi item `Persekitaran institusi menjadi benteng untuk diri saya dari melakukan perkara yang tidak berakhlak.' sehingga Skor Min 3.83 ( $\mathrm{SP}=0.76)$ bagi item 'Persekitaran institusi faktor pendorong yang kuat untuk saya mengamalkan sikap dan tingkah laku berakhlak.' pada tahap sederhana tinggi. Kesemua item berada pada tahap sederhana tinggi, dapatan memperlihatkan persekitaran institusi mempunyai pengaruh yang sederhana tinggi dalam pembentukan akhlak pelajar. Persekitaran institusi perlu dirancang dengan baik kerana ianya memberi pengaruh dalam pembentukan akhlak pelajar. Ini selari dengan pelaksanaan Islamic Enviorement di jabatan induk dan sokongan, sudut-sudut motivasi dan sebagainya. 
6. Pengaruh Masyarakat

Jadual 9: Taburan skor Pengaruh Masyarakat

\begin{tabular}{|c|c|c|c|}
\hline Item & Min & SP & Tahap \\
\hline Cara hidup masyarakat menjadi panduan akhlak diri saya. & 3.73 & 0.77 & ST \\
\hline $\begin{array}{l}\text { Tindakan yang diambil terhadap salah laku remaja melalui } \\
\text { peraturan masyarakat mempengaruhi pembentukan akhlak diri saya. }\end{array}$ & 3.68 & 0.78 & ST \\
\hline $\begin{array}{l}\text { Cara hidup masyarakat yang positif menjadi faktor pendorong yang kuat untuk } \\
\text { saya melakukan perkara yang berakhlak. }\end{array}$ & 3.95 & 0.73 & ST \\
\hline $\begin{array}{l}\text { Budaya hidup yang positif dalam masyarakat menjadi benteng untuk diri saya } \\
\text { dari melakukan perkara yang tidak berakhlak. }\end{array}$ & 3.89 & 0.82 & ST \\
\hline Keseluruhan & 3.81 & 0.60 & ST \\
\hline
\end{tabular}

Sumber: Data Lapangan SP: Sisihan Piawai

R: Rendah SR: Sederhana Rendah

ST: Sederhana Tinggi T: Tinggi

Merujuk kepada jadual di atas, tahap pengaruh masyarakat dalam pembentukan akhlak pelajar berada pada tahap sederhana tinggi (Skor Min 3.81, SP=0.60). Skor Min adalah antara 3.68 (SP=0.78) bagi item `Tindakan yang diambil terhadap salah laku remaja melalui peraturan masyarakat mempengaruhi pembentukan akhlak diri saya.' iaitu pada tahap sederhana tinggi sehingga Skor Min 3.98 (SP=0.73) bagi item 'Cara hidup masyarakat yang positif menjadi faktor pendorong yang kuat untuk saya melakukan perkara yang berakhlak' pada tahap sederhana tinggi. Kesemua item berada pada tahap sederhana tinggi. Hasil kajian mendapati pelajar yang datang dari pelbagai latar belakang masyarakat mengatakan bahawa masyarakat memberi pengaruh dalam pembentukan akhlak pelajar pada tahap yang sederhana tinggi melebihi rakan sebaya. Pentingnya bagi masyarakat kekal dan meningkatkan lagi keupayaan memberikan pengaruh yang positif dan terhadap pembentukan akhlak remaja.

7. Pengaruh Undang-undang

Jadual 10: Taburan skor Pengaruh Undang-undang

\begin{tabular}{llll} 
Item & Min & SP & Tahap \\
\hline Undang-undang negara menjadi panduan akhlak diri saya. & 3.76 & 0.84 & ST \\
$\begin{array}{l}\text { Tindakan yang diambil terhadap salah laku golongan remaja melalui } \\
\text { undang-undang dalam negara mempengaruhi pembentukan akhlak diri }\end{array}$ & 3.67 & 0.83 & ST \\
$\begin{array}{l}\text { saya. } \\
\begin{array}{l}\text { Undang-undang mendorong saya mengamalkan sikap dan tingkah laku } \\
\text { berakhlak. }\end{array}\end{array}$ & 3.79 & 0.85 & ST \\
$\begin{array}{l}\text { Undang-undang negara menjadi benteng untuk diri saya dari melakukan } \\
\text { perkara yang tidak berakhlak. }\end{array}$ & 3.74 & 0.92 & ST \\
KESELURUHAN & 3.74 & 0.73 & ST \\
\hline Sul
\end{tabular}

Sumber: Data Lapangan SP: Sisihan Piawai

R: Rendah SR: Sederhana Rendah

ST: Sederhana Tinggi T: Tinggi

Merujuk kepada jadual di atas, tahap pengaruh undang-undang dalam pembentukan akhlak anak-anak berada pada tahap sederhana tinggi (Skor Min 3.74, SP=0.73) secara keseluruhannya. Skor Min adalah antara 3.67 ( $\mathrm{SP}=0.83$ ) bagi item 'tindakan yang diambil terhadap salah laku golongan remaja melalui undang-undang dalam negara mempengaruhi pembentukan akhlak diri saya' sehingga Skor Min 3.79 ( $\mathrm{SP}=0.85)$ bagi item 'undang-undang menjadi faktor pendorong yang kuat untuk saya mengamalkan tingkah laku yang berakhlak'. Kesemua item berada pada tahap sederhana tinggi, dapatan memperlihatkan bahawa undang-undang mempunyai pengaruh yang sederhana tinggi dalam pembentukan akhlak pelajar. Pelajar yang merupakan remaja melihat undang-undang sebagai satu mekanisme untuk berakhlak berkemungkinan atas faktor hormat kepada undang-undang atau menjadikan sebagai batasan dalam bertingkahlaku agar tidak dikenakan tindakan undangundang. 
Jadual 11: Pengaruh Persekitaran Sosial

\begin{tabular}{llll} 
Pengaruh Persekitaran Sosial & Min & SP & Tahap \\
\hline Ibu bapa & 4.25 & 0.57 & T \\
Pensyarah & 3.97 & 0.61 & ST \\
Masyarakat & 3.81 & 0.60 & ST \\
Persekitaran Institusi & 3.76 & 0.59 & ST \\
Undang-undang & 3.74 & 0.73 & ST \\
Rakan Sebaya & 3.63 & 0.62 & ST \\
Artis & 2.80 & 0.93 & ST \\
Keseluruhan & 3.74 & 0.73 & SR \\
\hline
\end{tabular}

Sumber: Data Lapangan SP: Sisihan Piawai

R: Rendah SR: Sederhana Rendah

ST: Sederhana Tinggi T: Tinggi

Jadual di atas memerihalkan perbandingan skor Min bagi kesemua pemboleh ubah pengaruh persekitaran sosial yang dikaji. Dapatan menunjukkan bahawa ibu bapa (Skor Min 4.25, SP=0.57) paling berpengaruh dalam pembentukan peribadi pelajar iaitu berada pada tahap tinggi. Ini kemudiannya diikuti dengan pengaruh pensyarah (Skor Min 3.97, SP=0.61), masyarakat (Skor Min 3.81, SP=0.60), persekitaran institusi (Skor Min 3.76, $\mathrm{SP}=0.59$ ), undang-undang (Skor Min 3.74, $\mathrm{SP}=0.73$ ) dan rakan (Skor Min 3.63, SP=0.62) iaitu berada pada tahap sederhana tinggi. Artis (Skor Min 2.80, SP=0.93) dilihat kurang memberi pengaruh kepada pembentukan peribadi pelajar berada pada tahap sederhana rendah.

\section{KESIMPULAN}

Akhlak merupakan satu elemen yang terpenting sebagai hamba dan khalifah Allah swt di muka bumi ini dan merupakan tujuan utama perutusan nabi Muhammad saw. Segala syariat melalui al-Quran dan as-Sunnah bermatlamatkan membina dan memartabatkan akhlak dalam kehidupan Muslim. Remaja yang merupakan gambaran masa depan negara dan dunia perlu dimantapkan dengan akhlak mulia sedari kecil dan memerlukan komitmen semua pihak. Hasil kajian ini dapat dirumuskan bahawa ibubapa sangat signifikan mempengaruhi pembentukan akhlak anak-anak. Kajian mendapati ibubapa mempunyai pengaruh yang tertinggi dalam membentuk akhlak pelajar. Hanya satu aspek sahaja dalam kajian ini berada pada tahap tinggi iaitu ibubapa manakala 5 aspek berada pada tahap sederhana tinggi dan satu aspek berada pada tahap sederhana rendah. Pensyarah juga amat signifikan memperlihatkan mempunyai pengaruh yang kedua tertinggi dalam membentuk akhlak pelajar. Keadaan ini selari dengan Pelan Pembangunan Pendidikan Malaysia 2015-2025 (Pendidikan Tinggi) yang bermatlamatkan pembinaan akhlak. Pensyarah perlu memantapkan peranannya dalam membangunkan akhlak pelajar kerana guru mampu memberi pengaruh yang baik selain daripada masyarakat, institusi, undang-undang dan rakan. Kajian ini mendapati artis tidak memberi pengaruh kepada pembentukan akhlak berkemungkinan artis tidak menjadi ikutan pelajar atau pelajar hanya menganggap artis sebagai elemen hiburan sahaja. Selain itu, remaja perlu dibekalkan pengetahuan agama yang kukuh kerana agama Islam itu sendiri yang bersifat sempurna dan universal (Abdullah Nasih Ulwan, 2003).

\section{DAFTAR RUJUKAN}

Azhar Ahmad (2006) Strategi Pembelajaran Pengaturan Kendiri Pendidikan Islam dan Penghayatan Akhlak Pelajar Sekolah Menengah di Sarawak. Tesis Dr. Falsafah. Bangi:UKM.

Abul Qasem, Muhammad (1975). The Ethics of al-Ghazali: A Composite Ethic in Islam. US: The University of California.

Ibn Khaldun ( 2002) Abd al-Rahman bin Muhammad Khaldun al-Hadrami Mukaddimah Ibn Khaldun. Terj. Dewan Bahasa dan Pustaka. Kuala Lumpur : Dewan Bahasa dan Pustaka.

Umaruddin, M. (2003). The Ethical Philosophy of al-Ghazali. India: Adam Publishers.

Badrulzaman, B. (2006). Persekitaran keluarga dan kesannya terhadap tingkah laku devian remaja di daerah Pontian, Johor, Fakulti Pendidikan: Universiti Teknologi Malaysia.

Hassan Langgulung (1987). Asas-asas Pendidikan Islam. Kuala Lumpur: Dewan Bahasa dan Pustaka.

Ab. Halim Tamuri \& Zarin Ismail (2005). Hubungan Media Massa Dengan Pegangan Akhlak dan Pengajaran Pendidikan Islam. Laporan Penyelidikan UKM. Bangi: Universiti Kebangsaan Malaysia.

Buerah Tunggak, Maznah Ali, Nurafzan Muhamad \& Md. Hamzaimi Azrol Md Baharuddin. (2012). Delinkuensi Pelajar dan Cadangan Penyelesaiannya Menerusi Model Pembangunan Sahsiah Remaja/ 
Pelajar Muslim Bersepadu. Seminar Antarabangsa Perguruan\& Pendidikan Islam: Le Grandeur Palm Resort, Senai, Johor Baru. 08-09 Mac 2012.

Ahmad Syukri. (2008). Pengaruh Media Massa dan Media Elektronik dalam Mensosialisasikan Masyarakat di Provinsi Riau. Jurnal Penelitian, Vol VIII No 4 September 2008, hal, 38-45.

Fariza Md Sham dan Muhammad Faisal Ashaari (2010). Media sebagai Tarikan Psikologi Dalam Dakwah. Kertas Kerja Muzakarah Ulama’ dan Cendiakawan Islam 2010. 31 Mei 2010. Perak: Pejabat SUK Negeri Perak.

Zainudin Sharif \& Norazmah Mohamad Roslan (2011). Faktor-Faktor Yang Mempengaruhi Remaja Terlibat Dalam Masalah Sosial Di Sekolah Tunas Bakti, Sungai Lereh, Melaka. Journal of Education Psychology \& Counseling, volume 1 Mac 2011, Pages115-140

Creswell, J. W. (2008). Research design: Qualitative, quantitative, and mixed methods approaches (3rd ed.). Thousand Oaks, CA: Sage Publications.

Krejcie, R.V. \& Morgan, D.W. (1970). Determining sample size for research activities. Educational \& Psychological Measurement, 30, 607-610.

Abdullah Nasih Ulwan (2003). Generasi Muda \& Cabaran Globalisasi. Kuala Lumpur: YADIM. 